\title{
Evaluation of Capital Structure of Agricultural Cooperatives
}

\author{
J. Steklá, M. Gryčová, J. Homolka
}

Faculty of Economics and Management, Czech University of Life Sciences Prague, Czech Republic

\begin{abstract}
Anotace
Jedním z významných faktorů ovlivňujících ekonomickou efektivnost je vhodná kapitálová vybavenost podniků. V prŕípadě správného nastavení kapitálové struktury, přesněji řečeno poměru vlastního kapitálu a cizího kapitálu, je třeba vzít v úvahu několik faktorů, které působí na strukturu kapitálu, např́klad různé zdroje financování. Hlavním cílem této práce je analyzovat vývoj struktury kapitálu a kapitálové disparity v zemědělských družstvech v rámci čtrnácti krajů České republiky pro časovou řadu 2009 - 2013. Pro tuto analýzu jsou použity ukazatele zadluženosti a metody komparativní statiky. Data jsou získána a zpracována z databáze podniků Albertina. Finanční a ekonomická krize snížila dluhové finanční indikátory, stejně tak i indikátory zisku. Kapitálová disparita mezi regiony na konci sledovaného období se zdá nezměněna. Obvykle Praha jako region s nejvyšším HDP na obyvatele během sledovaného období vykazuje extrémní hodnoty většiny indikátorů a vyšší odchylky v dluhových finančních indikátorech a nižší v indikátorech ziskovosti. Vliv indikátorů kapitálové struktury na ziskovost družstev se zdá nevýznamný během sledovaného období.
\end{abstract}

\section{Klíčová slova}

Kapitálová struktura, disparita, zemědělská družstva, kraje.

\begin{abstract}
One of the major factors, which affect the economic effectiveness, is suitable capital facilities of enterprises. In case of correct adjustment of capital structure, more precisely the ratio of equity capital and foreign capital, it is necessary take into account a number of factors which operate on the structure of capital, for example a variety of funding sources. The main aim of this paper is to analyze the development of the capital structure and capital disparity across the farmers' cooperatives from fourteen regions of the Czech Republic for time series 2009 - 2013. For this analysis is used the debt leverage indicators and method of comparative statics. Data are obtained and processed from the database of enterprises of Albertina. The financial and economic crisis lowered the debt to equity ratio and debt to assets ratio and the profitability ratios as well and the indicators reports V-shaped trend. The disparity of the ratio values among regions at the end of the monitored period seems not to be changed. Usually Prague as the region with the highest GDP per capita during the monitored period reports usually the extreme values in most ratios and higher deviations in debt ratios and lower deviations in profitability ratios. Also the impact of capital structure indicators on the profitability of cooperatives seems to be not significant during the monitored period.
\end{abstract}

\section{Key words}

Capital structure, disparity, farmers' cooperatives, regions.

\section{Introduction}

The agricultural sector is an important part of an economy and has its own specifics. Its specificities are primarily of seasonal nature of production and dependence on natural conditions. These specifics are reflected in the economic results of farm enterprises, which affecting their capital structure, thereby arise capital disparity.
It is important to find out an optimal capital structure. The enterprises that are situated too far from the optimum faced greater risk of failure. The businesses make efforts to increase leverage when they face growth opportunities or when poor performances reduce equity value. The enterprises could gain advantage when rapid growth reduces financial slack. 
Financial indicators, which influence capital structure, are mentioned in many studies. For example Rosochatecká (2002) mentions this problem, or Gurčík (2002), Chrastinová (2004) etc.

Capital structure has two main theories. It is the optimal trade-off theory and the pecking order theory. The first one was mentioned by Kraus and Litzenberger (1973), Jensen and Meckling (1976) and Morellec (2004). The second one is mentioned by, for example, Donaldson (1961) and Myers and Majluf (1984).

Kraus and Litzenberger (1973) emphasized that there exists balance between the tax debt and the bankruptcy. But Choi (2015) mentioned that debt is not one-sided. Jensen and Meckling (1976) found out that managers with mixed financial structure of an enterprise include debt, choose such activities for enterprises that decrease the value of the enterprise. Their theory is called the theory of agency costs and is a part of trade-off theory. Morellec (2004) said that optimal capital structure reflects the tax debt bankruptcy costs and the agency costs of managerial discretion. On the other side, within pecking order theory, Donaldson (1961) found out that management needs internal financing as a source of a new fund and does not need external financing. Myers and Majluf (1984) in their study said that external financing by debt is quite better than financing by equity.

According to the optimal trade-off theory, taxes and costs combine to yield, thereby is acquired an optimal capital structure. And the enterprises are punished for deviating from that optimum in form of lower risk-adjusted returns, and potentially failure. On the basis the pecking order theory, capital structure is a result of investment opportunities in the presence of asymmetric information. The enterprises are faced to the new investment opportunities and they strive to moderate unfavorable selection costs and so they seek use the least risky forms of financing. The leverage is increased when there are a lot of investment opportunities and the demand for investment capital is high. The other way around the leverage is decreased when there are not much investment opportunities and cash flow is considerable. The enterprises are punished that they have not enough financial slack on investments or they do not keep more slack than is optimal.

The leverage was mentioned and the difference of this ration was used by Welch (2011), Fama and French (2005), Lemon, Roberts and Zender
(2008), DeAngelo and DeAngelo (2007). Welch (2005) gave a definition of leverage as total liabilities to total assets. He mentioned that a lot of authors define leverage as debt divided by assets, but it is incorrect according by his study. He proved that the best definition for leverage is the liabilities to assets, or if the managers want to focus on financial leverage, they can use definition as debt to capital. Fama and French (2005) used the same definition for leverage as Welch (2005) but Welch (2005) added that financial debt and non-financial liabilities as the same as equity. Baker and Wurgler (2002) defined leverage as debt divided by total assets. This definition follows the study from Fama and French (2005) and they suppose convertible debt. Lemon, Roberts and Zender (2008) define leverage as debt to total assets, i.e. sum of total debt and market equity. The same definition use DeAngelo and DeAngelo (2007). And they mentioned that the important is tax advantage of debt.

Minton and Wruck (2001) mentioned that the enterprises which have quite low leverage have quite high, or rather normal, book-to-market ratio. This effect is not specific to particular industries. In addition the enterprises do not have low tax rates, high non-debt tax shelters or information asymmetries. Shivdasani and Stefanescu (2010) mentioned that the enterprises are less conservative in their choices of leverage and they informed that the enterprises incorporate the magnitudes of pension liabilities in their capital structure decisions. Lemmon, Roberts and Zender (2008) found out that regression of leverage ratios do not explain, and is inadequate, for heterogeneity in capital structure. Graham and Leary (2011) found out that standard variables used to explain capital structures have little ability to explain variation.

The main aim of this paper is to analyze the development of the capital structure and capital disparity across the farmers' cooperatives from fourteen regions in the Czech Republic for time series 2009 - 2013 using the statistical analysis and correlation analysis.

The main objective of this study is to find out the impact of capital structure on the profitability of the farmers' cooperatives. Some other specific objectives are:

i) To identify the profitability of farmers' companies over the period of study.

ii) To identify and to analyze the relationship between profitability and capital structure. 


\section{Materials and methods}

Data were obtained from the database Albertina for time series 2009 - 2013. There were analyzed 493 farmers' cooperatives which belong to the section Agriculture, according to CZ-NACE, with focusing on crop and agriculture production. The farmers' cooperatives were divided into regions, i.e. 68 farmers' cooperatives in Central Bohemia region, 64 in Highland region, 14 in Karlovy Vary region, 20 in Hradec Králové region, 18 in Liberec region, 20 in Moravia-Silesia region, 43 in Olomouc region, 32 in Pardubice region, 30 in Pilsen region, 9 in Prague region, 81 in South Bohemia region, 49 in South Moravia region, 15 in Ústí region and 30 in Zlín region.

The most farmers' cooperatives farmed in South Bohemia region (15.0\%, i.e. 356382 ha), followed by the Central Bohemia region (13.4\%, i.e. 294284 ha), South Moravia region (284 859 ha) and Vysočina region (271 $078 \mathrm{ha}$ ). The agricultural holdings with the agricultural land area from 10 to 50 ha (and also to $5 \mathrm{ha}$ ) are the most in the Central Bohemia region, followed by Central Bohemia region. The largest part of the farmed agricultural land belongs to the Central Bohemian region (15.8\%) and South Bohemia region $(12.0 \%)$. The smallest part of the farmed agricultural land belongs to the region of Prague (10 771 ha), Karlovy Vary region (59 771 ha) and Liberec region (62 $434 \mathrm{ha}$ ). The vast majority of the farmed agricultural land $(71.3 \%)$ consists of the arable land, except for the Liberec region $(34.1 \%)$, where the permanent grassland predominate $(65.8 \%)$. The largest percentage of arable land is in the South Moravian region $(88.8 \%)$, in the Central Bohemia region including Prague $(87.4 \%)$, where the acreage of grassland is the smallest $(6.1 \%$ and $11.6 \%)$. The cereals accounted for the largest share on the arable land in all the regions. It is the most in the South Moravian region (64.7 \%) and Ústí region $(64.0 \%)$, the least in Pardubice region $(51.1 \%)$ and Vysočina region $(51.7 \%)$. The wheat fields account for half of the cereal areas (Olomouc region, $51.8 \%$ ) and two thirds (Ústí region, $68.5 \%$ ). The maize accounts for a significant share in the South Moravia region (44.8\% of the area). The potato growing is concentrated in the Vysočina region $(37.8 \%)$ and in the Central Bohemia region $(24.0 \%)$. The largest share areas of sugar beets $(27.7 \%)$, colza $(21.5 \%)$, other oil plants (soybeans $20.1 \%$ ) and vegetables $(40.1 \%)$ are in the Central Bohemia region. The biggest area of sunflowers $(50.3 \%)$ and flax $(97.7 \%)$ are in the South Moravia region (Regionální vyhodnocení výsledků FSS, 2013; Využití obhospodařované zemědělské půdy, 2013; Statistické ročenky, 2014).

In this paper are used the following formulas, i.e. relative indicators:

a) Debt to equity ratio $(\mathrm{D} / \mathrm{E})$. This ratio (Leavy, 2004) is a financial ratio that indicates the relative proportion of shareholders' equity and debt which is used to finance a company's assets. Because of closely relating to leverage, this ratio is also known as Risk, Gearing or Leverage. It can be calculated as total liabilities divided by total equity.

b) Debt to assets ratio (D/A). This ratio (Welch, 2011) is the debt, i.e. liabilities, plus equity equals assets. Ratio shows the proportion of a company's assets which are financed through debt. The enterprises with high debt could be in danger if creditors start to demand repayment of debt. It can be calculated as total liabilities divided by total assets.

c) Interest coverage ratio ( $\mathrm{ICr}$ ). The formula for the interest coverage ratio (Faulkender, Wang, 2006) used to measure a company's earnings relative to the amount of interest that they pay. It can be calculated as earnings before interest and taxes divided interest expense.

d) Gross profit ratio (GPr). This ratio (Peterson, Fabozzi, 1999) is important for business. It should be sufficient to cover all expenses and moreover provide for profit. Ratio is also known as gross profit margin or gross profit percentage. It can be calculated as gross profit divided by net sales.

e) Net profit ratio (NPr). According to this ratio (Guthmann, Dougall, 1955), net profit is equal to gross profit minus operating expenses and income tax. Net profit ratio is a useful tool to measure the overall profitability of the enterprises. It can be calculated as net profit after tax divided by net sales.

f) Return on capital employed (ROCE). This ratio (Gill et al., 2011) measures a company's profitability and the efficiency with which its capital is employed. The capital employed is the sum of shareholders' equity and debt liabilities or total assets minus current liabilities. It can be calculated as earnings before interest and taxes divided by total assets minus current liabilities. 
In this paper is used the Pearson's Correlation coefficient (King, Rosopa, Minium, 2011) which is a statistical measure of the strength of a linear correlation between two variables $\mathrm{X}$ and $\mathrm{Y}$. Where 1 is total positive correlation, 0 is no correlation, and -1 is total negative correlation. This coefficient is defined as the covariance of the two variables divided by the product of their standard deviations. Formula for Pearson's Correlation coefficient is:

$$
r=\frac{\sum_{i=1}^{n}\left(X_{i}-\bar{X}\right) \cdot\left(Y_{i}-\bar{Y}\right)}{\sqrt{\sum_{i=1}^{n}\left(X_{i}-\bar{X}\right)^{2}} \sqrt{\sum_{i=1}^{n}\left(Y_{i}-\bar{Y}\right)^{2}}}
$$

There is also used the coefficient of determination. Coefficient of determination (Hirschey, 2008) is used in multiple regression models where more than one independent $\mathrm{X}$ variable is considered. The coefficient shows how well a multiple regression model explains changes in the value of the dependent $\mathrm{Y}$ variable. This coefficient can be calculated as (Lang, Secic, 2006):

$$
R^{2}=\frac{\text { variation explained by regression }}{\text { total variation in } Y}
$$

The minor hypothesis used in this paper based on the theoretical background about the regional development used in this paper states that the region with higher GDP per capita (i.e. Prague) performs the values for debt ratios in average lower and the deviation higher during and after the crisis than the region with a low GDP per capita (e.g. Karlovy Vary or Liberec) according to the average of the period 2009-2013. The opposite might be true for the profitability ratios.

\section{Results and discussion}

Firstly, the calculated values for each ratio are listed in the following tables with their mean and standard deviation with respect to the regions.

The table no. 1 summarizes the results for the debt to equity ratio in every Czech region. The region with the highest average value during the monitored period is Liberec and the lowest value is in the region of Ústí (Prague is just the second). The region with the highest standard deviation is Liberec (Prague is just second one) that means that the crisis hit this region the most and so that the ratio changes the most during the period of 2009-2013. On the contrary, the region whose ratio varies the least is Karlovy Vary which is accordingly with the hypothesis. The calculated values are just around or below the general optimum level of 1 . There is a decreasing trend during the recovery, but in 2013 there is an upward move in most regions. The highest variation range was in the year 2009 and in the regional point of view it was the region of Prague that means that in this region the value of the debt to equity ratio varied the most during the monitored period, that it could be said that the crisis and the recovery period affected the region of Prague the most. The regional

\begin{tabular}{|l|c|c|c|c|c|c|c|c|}
\hline CR regions & $\mathbf{2 0 0 9}$ & $\mathbf{2 0 1 0}$ & $\mathbf{2 0 1 1}$ & $\mathbf{2 0 1 2}$ & $\mathbf{2 0 1 3}$ & Mean & St. Dev. & C. V. \\
\hline Central Bohemia & 0.723 & 0.663 & 0.599 & 0.629 & 0.631 & 0.649 & 0.042 & 0.124 \\
\hline Highland & 0.978 & 0.974 & 0.915 & 0.903 & 0.944 & 0.943 & 0.030 & 0.075 \\
\hline Karlovy Vary & 0.702 & 0.709 & 0.716 & 0.655 & 0.689 & 0.694 & $\mathbf{0 . 0 2 2}$ & 0.061 \\
\hline Hradec Králové & 0.952 & 0.850 & 0.599 & 0.594 & 0.613 & 0.722 & 0.150 & 0.359 \\
\hline Liberec & 1.581 & 1.563 & 1.155 & 1.077 & 1.001 & $\mathbf{1 . 2 7 5}$ & $\mathbf{0 . 2 4 7}$ & 0.580 \\
\hline Moravian-Silesian & 0.952 & 0.850 & 0.599 & 0.594 & 0.657 & 0.730 & 0.145 & 0.358 \\
\hline Olomouc & 0.665 & 0.606 & 0.517 & 0.537 & 0.565 & 0.578 & 0.053 & 0.148 \\
\hline Pardubice & 0.910 & 0.843 & 0.766 & 0.754 & 0.702 & 0.795 & 0.073 & 0.208 \\
\hline Pilsen & 0.956 & 0.844 & 0.763 & 0.844 & 0.893 & 0.860 & 0.064 & 0.193 \\
\hline Prague & 0.302 & 0.425 & 0.467 & 0.662 & 0.759 & 0.523 & 0.165 & $\mathbf{0 . 4 5 7}$ \\
\hline South Bohemia & 0.905 & 0.926 & 0.890 & 0.809 & 0.838 & 0.874 & 0.043 & 0.117 \\
\hline South Moravia & 0.923 & 0.929 & 0.799 & 0.797 & 0.825 & 0.855 & 0.059 & 0.132 \\
\hline Ústí & 0.553 & 0.541 & 0.526 & 0.473 & 0.512 & $\mathbf{0 . 5 2 1}$ & 0.028 & 0.080 \\
\hline Zlín & 0.751 & 0.705 & 0.659 & 0.581 & 0.634 & 0.666 & 0.058 & 0.170 \\
\hline C. V. & $\mathbf{1 . 2 7 9}$ & 1.138 & 0.688 & 0.604 & 0.489 & - & - & - \\
\hline
\end{tabular}

Source: Albertina database, Czech Republic; own calculations

Table 1: Debt to equity ratio [Figures in times], 2009-2013. 
differences lowered during the crisis in this ratio and during the recovery as well.

The table no. 2 lists the results for the debt to assets ratio in every region. The region with the highest average value during the monitored period is Liberec again and the lowest value is in Prague. The region with the highest standard deviation is Prague that means that the crisis hit this region the most and so that the ratio changes the most during the period. The regions whose ratios vary the least are Karlovy Vary and Highland. The results are quite in accordance with the paper main hypothesis. Also the calculated values in regions are in the range of the general optimum level of 0.5 . There could be also find a V-shaped trend during the monitored period, but rather decreasing with the top values in the year of 2009. The highest variation range was also in the year 2009 , the year of the crisis, and in the regional point of view it was the region of Prague that means that in this region the value of the debt to assets ratio changed the most during the monitored period, that it could be said that the crisis and the recovery period affected the region of Prague the most. Also the regional differences lowered during the crisis in this ratio and during the recovery as well but a slow little upward trend in 2013.

The table no. 3 contains the calculated values of the interest coverage ratio for each region. The region with the highest average value during the monitored period is Zlín and the lowest value is in Prague. The region with the highest standard deviation is Ústí that means that the interest coverage varies the most in this region during the period. The region whose ratio varies the least is Prague that is in accordance with the idea that more developed region has a more stable interest rate. The region with the highest variation range was Ústí that means that the Interest coverage ratio changed the most during this period and so that the interest were the least stable for that region as expected by the theory and the highest variation range was in the crisis year of 2009 when counting all regions. Thus the regional differences lowered during the crisis in this ratio but then during the recovery started to rise again.

The table no. 4 shows the results for the gross profit ratio in every region. The region with the highest average value during the monitored period is Zlín and the one with the lowest value is Prague. The regions with the highest standard deviation are South Bohemia and South Moravia that means that the ratios there change the most during the period. The region with the lowest variance is Karlovy Vary. The region with the smallest ratio in 2009 is Prague. However, it is hard to find out any common trend because of the dependence of agricultural sector on weather and other agro-environmental conditions and the harvest values, even though there can be seen some increasing trend during the recovery and usually the value in 2013 is higher than in 2009. As expected, the values are lower than in other sectors. The region with the highest variation range was South Bohemia that means

\begin{tabular}{|l|c|c|c|c|c|c|c|c|}
\hline CR regions & $\mathbf{2 0 0 9}$ & $\mathbf{2 0 1 0}$ & $\mathbf{2 0 1 1}$ & $\mathbf{2 0 1 2}$ & $\mathbf{2 0 1 3}$ & Mean & St. Dev. & C. V. \\
\hline Central Bohemia & 0.420 & 0.399 & 0.375 & 0.386 & 0.399 & 0.396 & 0.015 & 0.045 \\
\hline Highland & 0.492 & 0.491 & 0.475 & 0.475 & 0.477 & 0.482 & $\mathbf{0 . 0 0 8}$ & 0.017 \\
\hline Karlovy Vary & 0.413 & 0.415 & 0.417 & 0.396 & 0.404 & 0.409 & $\mathbf{0 . 0 0 8}$ & 0.021 \\
\hline Hradec Králové & 0.488 & 0.457 & 0.374 & 0.373 & 0.389 & 0.416 & 0.047 & 0.115 \\
\hline Liberec & 0.613 & 0.610 & 0.536 & 0.519 & 0.511 & $\mathbf{0 . 5 5 8}$ & 0.045 & 0.102 \\
\hline Moravian-Silesian & 0.488 & 0.457 & 0.374 & 0.373 & 0.391 & 0.417 & 0.047 & 0.116 \\
\hline Olomouc & 0.399 & 0.377 & 0.341 & 0.349 & 0.352 & 0.364 & 0.021 & 0.058 \\
\hline Pardubice & 0.477 & 0.457 & 0.434 & 0.430 & 0.428 & 0.445 & 0.019 & 0.049 \\
\hline Pilsen & 0.489 & 0.458 & 0.433 & 0.444 & 0.467 & 0.458 & 0.019 & 0.056 \\
\hline Prague & 0.232 & 0.298 & 0.318 & 0.398 & 0.425 & $\mathbf{0 . 3 3 4}$ & $\mathbf{0 . 0 7 0}$ & $\mathbf{0 . 1 9 3}$ \\
\hline South Bohemia & 0.475 & 0.481 & 0.471 & 0.447 & 0.463 & 0.467 & 0.012 & 0.034 \\
\hline South Moravia & 0.480 & 0.482 & 0.444 & 0.443 & 0.441 & 0.458 & 0.019 & 0.041 \\
\hline Ústí & 0.356 & 0.351 & 0.345 & 0.321 & 0.302 & 0.335 & 0.020 & 0.054 \\
\hline Zlín & 0.429 & 0.414 & 0.397 & 0.368 & 0.336 & 0.389 & 0.033 & 0.093 \\
\hline C. V. & $\mathbf{0 . 3 8 1}$ & 0.312 & 0.218 & 0.198 & 0.209 & - & - & - \\
\hline
\end{tabular}

Source: Albertina database, Czech Republic; own calculations 


\begin{tabular}{|l|c|c|c|c|c|c|c|c|}
\hline CR regions & $\mathbf{2 0 0 9}$ & $\mathbf{2 0 1 0}$ & $\mathbf{2 0 1 1}$ & $\mathbf{2 0 1 2}$ & $\mathbf{2 0 1 3}$ & Mean & St. Dev. & C. V. \\
\hline Central Bohemia & 5.302 & 2.108 & 5.601 & 9.650 & 7.541 & 6.040 & 2.509 & 7.542 \\
\hline Highland & 3.321 & -0.844 & 3.790 & 6.885 & 8.987 & 4.428 & 3.354 & 9.831 \\
\hline Karlovy Vary & 0.998 & -0.318 & 0.101 & 2.265 & 2.843 & 1.178 & 1.215 & 3.161 \\
\hline Hradec Králové & 7.734 & 0.331 & 3.777 & 9.523 & 7.199 & 5.713 & 3.272 & 9.192 \\
\hline Liberec & 2.642 & -0.396 & 3.937 & 4.166 & 5.672 & 3.204 & 2.041 & 6.068 \\
\hline Moravian-Silesian & 7.734 & 0.331 & 3.777 & 9.523 & 9.920 & 6.258 & 3.675 & 9.589 \\
\hline Olomouc & 8.530 & -0.003 & 3.656 & 13.439 & 6.318 & 6.388 & 4.530 & 13.442 \\
\hline Pardubice & 5.648 & 1.096 & 5.212 & 8.583 & 9.825 & 6.073 & 3.035 & 8.729 \\
\hline Pilsen & 0.772 & 0.532 & 5.309 & 9.568 & 6.033 & 4.443 & 3.415 & 9.036 \\
\hline Prague & -0.003 & 0.007 & 0.009 & 0.008 & 0.006 & $\mathbf{0 . 0 0 4}$ & $\mathbf{0 . 0 0 6}$ & 0.016 \\
\hline South Bohemia & 3.481 & -1.540 & 3.789 & 7.698 & 8.502 & 4.386 & 3.583 & 10.042 \\
\hline South Moravia & 5.603 & -1.150 & 5.862 & 11.311 & 8.226 & 5.970 & 4.110 & 12.461 \\
\hline Ústí & 16.625 & 0.838 & -1.832 & 9.320 & 4.251 & 5.840 & $\mathbf{6 . 5 5 5}$ & $\mathbf{1 8 . 4 5 7}$ \\
\hline Zlín & 10.109 & 1.734 & 4.691 & 12.407 & 10.367 & $\mathbf{7 . 8 6 2}$ & 3.990 & 10.673 \\
\hline C. V. & $\mathbf{1 6 . 6 2 8}$ & 3.648 & 7.694 & 13.447 & 10.373 & - & - & - \\
\hline
\end{tabular}

Source: Albertina database, Czech Republic; own calculations

Table 3: Interest coverage ratio [Figures in times], 2009-2013.

\begin{tabular}{|l|c|c|c|c|c|c|c|c|}
\hline CR regions & $\mathbf{2 0 0 9}$ & $\mathbf{2 0 1 0}$ & $\mathbf{2 0 1 1}$ & $\mathbf{2 0 1 2}$ & $\mathbf{2 0 1 3}$ & Mean & St. Dev. & C. V. \\
\hline Central Bohemia & 0.033 & 0.006 & 0.036 & 0.058 & 0.047 & 0.036 & 0.017 & 0.052 \\
\hline Highland & 0.016 & -0.022 & 0.020 & 0.043 & 0.062 & 0.024 & 0.028 & 0.084 \\
\hline Karlovy Vary & -0.002 & -0.024 & -0.010 & 0.009 & 0.019 & -0.002 & 0.015 & 0.043 \\
\hline Hradec Králové & 0.037 & -0.006 & 0.019 & 0.056 & 0.086 & 0.038 & 0.031 & 0.092 \\
\hline Liberec & 0.012 & -0.022 & 0.025 & 0.022 & 0.011 & 0.010 & 0.017 & 0.047 \\
\hline Moravian-Silesian & 0.036 & -0.005 & 0.018 & 0.057 & 0.073 & 0.036 & 0.028 & 0.078 \\
\hline Olomouc & 0.046 & -0.014 & 0.012 & 0.053 & 0.084 & 0.036 & 0.034 & 0.098 \\
\hline Pardubice & 0.043 & -0.004 & 0.031 & 0.053 & 0.075 & 0.040 & 0.026 & 0.079 \\
\hline Pilsen & -0.003 & -0.009 & 0.035 & 0.058 & 0.063 & 0.029 & 0.030 & 0.072 \\
\hline Prague & -0.006 & 0.014 & 0.021 & 0.014 & 0.002 & $\mathbf{0 . 0 0 6}$ & 0.012 & 0.035 \\
\hline South Bohemia & 0.021 & -0.035 & 0.025 & 0.061 & 0.091 & 0.033 & $\mathbf{0 . 0 4 2}$ & $\mathbf{0 . 1 2 6}$ \\
\hline South Moravia & 0.038 & -0.023 & 0.034 & 0.065 & 0.087 & 0.040 & 0.037 & 0.11 \\
\hline Ústí & 0.078 & -0.021 & -0.023 & 0.044 & 0.059 & 0.027 & $\mathbf{0 . 0 4 2}$ & 0.101 \\
\hline Zlín & 0.061 & 0.006 & 0.029 & 0.069 & 0.095 & $\mathbf{0 . 0 5 2}$ & 0.031 & 0.089 \\
\hline C. V. & 0.084 & 0.049 & 0.059 & 0.083 & $\mathbf{0 . 0 9 7}$ & - & - & - \\
\hline
\end{tabular}

Source: Albertina database, Czech Republic; own calculations

Table 4: Gross profit ratio [Figures in times], 2009-2013.

that the Gross profit ratio changed the most during this period and so that the gross profits were the least stable in that region and the highest variation range was in 2013 when counting all regions. Thus the regional differences decreased during the crisis in this ratio but then during the recovery increased again.

The table no. 5 lists the calculated values of the net profit ratio with regional aspect. The region with the highest average value during the monitored period is Zlín and the one with the lowest value is Prague. The region with the highest standard deviation is Ústí that means that the ratio there changes the most during the period. The region with the lowest variance is Karlovy Vary and Prague. The region with the smallest (even negative) ratio in 2009 is Prague again. The trend for this monitored period is more or less V-shaped for most of the regions with minimum usually in 2010 


\begin{tabular}{|l|c|c|c|c|c|c|c|c|}
\hline CR regions & $\mathbf{2 0 0 9}$ & $\mathbf{2 0 1 0}$ & $\mathbf{2 0 1 1}$ & $\mathbf{2 0 1 2}$ & $\mathbf{2 0 1 3}$ & Mean & St. Dev. & C. V. \\
\hline Central Bohemia & 0.030 & 0.007 & 0.033 & 0.050 & 0.070 & 0.038 & 0.021 & 0.063 \\
\hline Highland & 0.015 & -0.017 & 0.021 & 0.039 & 0.056 & 0.023 & 0.025 & 0.073 \\
\hline Karlovy Vary & -0.005 & -0.011 & -0.010 & 0.009 & 0.013 & -0.001 & $\mathbf{0 . 0 1 0}$ & 0.024 \\
\hline Hradec Králové & 0.029 & -0.005 & 0.016 & 0.045 & 0.087 & 0.034 & 0.031 & $\mathbf{0 . 0 9 2}$ \\
\hline Liberec & 0.010 & -0.016 & 0.023 & 0.015 & 0.002 & 0.007 & 0.013 & 0.039 \\
\hline Moravian-Silesian & 0.030 & -0.006 & 0.015 & 0.046 & 0.078 & 0.033 & 0.028 & 0.084 \\
\hline Olomouc & 0.043 & -0.008 & 0.013 & 0.045 & 0.059 & 0.030 & 0.024 & 0.067 \\
\hline Pardubice & 0.036 & 0.001 & 0.028 & 0.044 & 0.068 & 0.035 & 0.022 & 0.067 \\
\hline Pilsen & -0.004 & -0.006 & 0.029 & 0.049 & 0.071 & 0.028 & 0.030 & 0.077 \\
\hline Prague & -0.010 & 0.009 & 0.021 & 0.016 & 0.003 & $\mathbf{0 . 0 0 8}$ & $\mathbf{0 . 0 1 0}$ & 0.03 \\
\hline South Bohemia & 0.020 & -0.030 & 0.026 & 0.053 & 0.045 & 0.023 & 0.029 & 0.083 \\
\hline South Moravia & 0.035 & -0.023 & 0.031 & 0.054 & 0.060 & 0.031 & 0.029 & 0.083 \\
\hline Ústí & 0.071 & -0.004 & -0.019 & 0.043 & 0.058 & 0.030 & $\mathbf{0 . 0 3 5}$ & 0.09 \\
\hline Zlín & 0.051 & 0.005 & 0.023 & 0.057 & 0.067 & $\mathbf{0 . 0 4 1}$ & 0.023 & 0.062 \\
\hline C. V. & 0.081 & 0.039 & 0.054 & 0.073 & $\mathbf{0 . 0 9}$ & - & - & - \\
\hline
\end{tabular}

Source: Albertina database, Czech Republic; own calculations

Table 5: Net profit ratio [Figures in times], 2009-2013.

and with the value of 2013 higher than in 2009 . The values are much lower than in other sector because of the specific characteristics of the agricultural business. Also the regions with the highest variation range were Hradec Králové and Ústí region that means that the Net profit ratio changed the most during this period and so that the net profit was the least stable for those regions as expected by the theory and the highest variation range was in 2013 when counting all regions. Thus the regional differences lowered during the crisis in this ratio but then during the recovery increased again.

The table no. 6 shows the calculated values of the return on capital employed in each region. The region with the highest average value during the monitored period is South Moravia and the one with the lowest value is Prague. The region with the highest standard deviation is South Moravia that means that the ratio there changes the most during the period. The region with the lowest variance is Liberec. The region with the smallest (even negative) ratio in 2009 is Prague again. The trend for this monitored period is again V-shaped for most of the regions with minimum usually in 2010 and with the value of 2013 higher than in 2009. Also the region with the highest variation range was South Moravia that means that the Return on capital employed ratio changed the most during this period and so that the returns on capital were the least stable for those regions and the highest variation range was in the year 2013 when counting all regions that could mean that the crisis and recovery period affected the region by increasing their return on capital employed disparity. So the regional differences lowered during the crisis in this ratio, but during the recovery the differences increased much more over the starting level.

Lastly, the table no. 7 sums up results of correlation analysis between all mentioned ratios using data for all regions in order to uncover the relationship between the capital structure and the profitability ratios.

The very high positive correlation between the debt to equity ratio and the debt to assets ratio is clearly deduced from the definition of those ratios. Also the gross profit ratio, the net profit ratio and the interest coverage ratio are very highly positively correlated among each other by the definition.

As assumed the relationships between the debt to equity ratio and the following ratios respectively, i.e. the interest coverage ratio, the gross profit ratio and the net profit ratio, are negative, but very close to zero. The correlation coefficients are equal to $-0.088,-0.064$ and -0.125 respectively. As assumed the correlation coefficients between the debt to assets ratio and the interest coverage ratio, the net profit ratio are negative, but again close to zero $(-0.035,-0.046$ respectively). The positive correlation coefficients between the debt to assets ratio and the gross profit ratio, the return on capital employed ratio are very low and close to zero, i.e. no relationship 


\begin{tabular}{|l|c|c|c|c|c|c|c|c|}
\hline CR regions & $\mathbf{2 0 0 9}$ & $\mathbf{2 0 1 0}$ & $\mathbf{2 0 1 1}$ & $\mathbf{2 0 1 2}$ & $\mathbf{2 0 1 3}$ & Mean & St. Dev. & C. V. \\
\hline Central Bohemia & 0.054 & 0.021 & 0.051 & 0.081 & 0.079 & 0.057 & 0.022 & 0.06 \\
\hline Highland & 0.030 & -0.008 & 0.034 & 0.062 & 0.088 & 0.041 & 0.032 & 0.096 \\
\hline Karlovy Vary & 0.010 & -0.003 & 0.002 & 0.024 & 0.056 & 0.018 & 0.021 & 0.059 \\
\hline Hradec Králové & 0.057 & 0.003 & 0.026 & 0.075 & 0.084 & 0.049 & 0.030 & 0.081 \\
\hline Liberec & 0.026 & -0.004 & 0.040 & 0.037 & 0.012 & 0.022 & $\mathbf{0 . 0 1 6}$ & 0.044 \\
\hline Moravian-Silesian & 0.058 & 0.002 & 0.027 & 0.078 & 0.099 & 0.053 & 0.035 & 0.097 \\
\hline Olomouc & 0.066 & 0.054 & 0.021 & 0.067 & 0.083 & 0.058 & 0.021 & 0.062 \\
\hline Pardubice & 0.068 & 0.012 & 0.046 & 0.075 & 0.092 & 0.059 & 0.028 & 0.08 \\
\hline Pilsen & 0.009 & 0.004 & 0.048 & 0.078 & 0.093 & 0.046 & 0.036 & 0.089 \\
\hline Prague & -0.010 & 0.042 & 0.067 & 0.040 & 0.023 & $\mathbf{0 . 0 2 0}$ & 0.036 & 0.109 \\
\hline South Bohemia & 0.033 & -0.015 & 0.035 & 0.074 & 0.075 & 0.040 & 0.033 & 0.09 \\
\hline South Moravia & 0.063 & -0.013 & 0.054 & 0.101 & 0.136 & $\mathbf{0 . 0 6 8}$ & $\mathbf{0 . 0 5 0}$ & $\mathbf{0 . 1 4 9}$ \\
\hline Ústí & 0.104 & 0.005 & -0.012 & 0.057 & 0.064 & 0.044 & 0.042 & 0.116 \\
\hline Zlín & 0.081 & 0.013 & 0.034 & 0.080 & 0.100 & 0.062 & 0.033 & 0.087 \\
\hline C. V. & 0.114 & 0.069 & 0.121 & 0.141 & $\mathbf{0 . 1 5 9}$ & - & - & - \\
\hline
\end{tabular}

Source: Albertina database, Czech Republic; own calculations

Table 6: Return on capital employed [Figures in times], 2009-2013.

\begin{tabular}{|l|c|c|c|c|c|c|}
\hline Variables & $\mathrm{D} / \mathrm{E}$ & $\mathrm{D} / \mathrm{A}$ & $\mathrm{ICr}$ & $\mathrm{GPr}$ & $\mathrm{NPr}$ & $\mathrm{ROCE}$ \\
\hline $\mathrm{D} / \mathrm{E}$ & 1.000 & & & & & \\
\hline $\mathrm{D} / \mathrm{A}$ & 0.985 & 1.000 & & & & \\
\hline $\mathrm{ICr}$ & -0.088 & -0.035 & 1.000 & & & \\
\hline $\mathrm{GPr}$ & -0.064 & 0.014 & 0.963 & 1.000 & & \\
\hline $\mathrm{NPr}$ & -0.125 & -0.046 & 0.969 & 0.968 & 1.000 & \\
\hline $\mathrm{ROCE}$ & 0.025 & 0.116 & 0.935 & 0.926 & 0.934 & 1.000 \\
\hline
\end{tabular}

Source: Albertina database, Czech Republic; own calculations

Table 7: Correlation matrices for capital structure and profitability ratios, all economic subjects together (Pearson Correlation), 2009-2013, 5\% critical value $($ two-tailed $)=0.5324$.

(the correlation coefficients equal 0.014 and 0.116 respectively). The same is true for the correlation between the debt to equity ratio and the return on capital employed ratio (the correlation coefficient is equal to 0.0285 ).

To conclude, during the crisis year and the recovery period the relationship between the capital structure ratios and profitability ratios is negligible and it is not statistical significant. This result acts for non-refusing the null hypothesis of this paper. Therefore, it can be said that during this monitored period the factors that influence the profitability are different from the capital structure changes for the cooperatives when adding the regional perspective.

The table no. 8 includes the main results of the regression analysis. All the models are statistical significant in consideration of the p-values of the F-tests.

An analysis of variance is used to measure effectiveness of the multiple regression models. The results of this analysis show that R-square for Debt to equity ratio is in size of 0.7764 . It indicates a relatively high portion ( 77.64 percent) of the total variation which is associated with the three explanatory variables of the multiple regression models. And the result for R-square for Debt to assets ratio is in size of 0.8847 ( 88.47 percent). It can be concluded that the debt to equity ratio and debt to assets ratio is determined by the variables included in the model. The variables which are tested in this study are Interest coverage ratio, Gross profit ratio, Net profit ratio and Return on capital employed.

The model explains the three of eight explanatory variables in the model are statistically significant 


\begin{tabular}{|l|c|c|c|}
\hline \multicolumn{2}{|c|}{ Debt to equity ratio } & \multicolumn{2}{c|}{ Debt to assets ratio } \\
\hline Variables & Parameter estimates & Variables & Parameter estimates \\
\hline ICr & 0.1598 & $\mathrm{ICr}$ & 0.1675 \\
\hline $\mathrm{GPr}$ & 0.1601 & $\mathrm{GPr}$ & 0.1722 \\
\hline $\mathrm{NPr}$ & 0.1498 & $\mathrm{NPr}$ & 0.1564 \\
\hline ROCE & -0.0389 & $\mathrm{ROCE}$ & -0.0453 \\
\hline
\end{tabular}

Source: Albertina database, Czech Republic; own calculations

Table 8: Test results of parameter estimates for ratios of capital structure, all economic subjects together, 2009-2013.

at the 10 percent level or better. The result presents that the interest coverage ratio, gross profit ratio and net profit ratio are significantly positively related to the debt to equity ratio and to the debt to assets ratio, while return on capital employed is significantly negatively related to the debt to equity ratio and to the debt to assets ratio.

\section{Conclusion}

The financial and economic crisis lowered the debt to equity ratio and debt to assets ratio and the profitability ratios as well. There is a decreasing $\mathrm{V}$-shaped trend in the mentioned financial indicators during the recovery. However, in 2013 there is an upward move in most regions, but still the value is below the level of 2009. Also the interest coverage ratio has a V-shaped trend with a minimum in 2010 for most of the regions. The trend of the gross profit ratio, net profit ratio and the return on capital employed ratio is also V-shaped with minimum in 2010 as well, and with the value of 2013 much higher than in 2009 in most of the regions. The disparity of the ratio values among regions at the end of the monitored period seems to be very similar to the one at the beginning of the monitored period.

The regional part of the hypothesis was only partly proved.

Usually Prague as the region with the highest GDP per capita and big investment possibilities during the monitored period reports usually the extreme values in most ratios, mainly in the debt to equity ratio (just the second lowest value), the debt to assets ratio and the interest coverage ratio, but in opposite direction than assumed by the paper hypothesis in the gross profit ratio, the net profit ratio and the return on capital employed ratio as well as mostly the regions with small GDP per capita during this period reports the opposite values. This can be explained by the other factors playing more important role in affecting the debt ratios and the profitability ratios than the regional development level as the agricultural sector has very specific characteristics.

The region that reports the opposite extreme values is Liberec in debt ratios and Zlín for most of the profitability ratios. The reasons behind the highest debt ratios in hilly region of Liberec might be the whole very high indebtedness of the Liberec region that levels off recent years. The region of Zlín and the region of South Moravia for the return on capital employed ratio might be the most profitable ones because of the residence of the one of the biggest agricultural holdings and because of the rich harvests thanks to favorable agro-environmental conditions.

The same is partly true for the standard deviations. The region of Prague reports higher deviations in debt ratios and lower deviations in profitability ratios. Also the variation range was the highest in the crisis year of 2009 for the debt ratios and for the interest coverage ratio and profitability ratios the leveling year is 2013. The lowest deviations in debt ratios are reported in the region of Karlovy Vary maybe because of the low investment possibilities so during the recovery period there is no room for booming and thus no high deviations from the levels of the ratio during the crisis. The reason might be also that in the region of Karlovy Vary there is a high concentration of highly indebted self-employed persons in agricultural sector that influences the capital structure and their profitability. Also the highest deviations in profitability ratios can be found in Ústí and South Moravia regions. The reason behind this result might be the high concentration of big holdings that are more affected by the crisis or by a bad harvest in those regions with very good agro-environmental conditions. So the profits change more than in other regions.

The crisis and the recovery period increase the variation range among the regions in the case of profitability ratios, i.e. the gross profit ratio 
and the net profit ratio and the return on capital employed ratio the most. This could be explained by the loosing of the negative effect of the crisis and by the recovery in the profitable regions and thus an increase in the differences across the regions. Conversely, the crisis and the recovery period decrease the variation range among the regions in the case of the debt ratios and the interest coverage ratio. The reason of smaller differences in the capital structure across the regions might be a cautiousness of the cooperatives in the agricultural sector during the monitored period in big investments connected with a higher indebtedness.

The calculated correlation coefficients uncovers that the relationship between the capital structure ratios and profitability ratios is negligible and statistical insignificant during the crisis year and the recovery period. Therefore, it can be said that during this monitored period the factors that influence the profitability are different from the capital structure changes for the cooperatives when adding the regional perspective. There can be also added that there exist factors which influence profitability (such as subsidies) and capital structure, or rather indebtedness, such as investments.

Our findings are consistent with other authors.
For example Taani (2013) state that debt to equity ratio is positively correlated return on capital employed. On the other hand Taani (2013) found out that debt to equity ratio is positively correlated with interest coverage ratio and net profit ratio, which is not consistent with our conclusion. Abor (2005) found out that debt to equity has a positive association with debt to assets. Mohammadzadeh et al. (2013) stated the negative relationship between the profitability and the ratios of capital structure.

This paper tried to contribute to the capital structure, capital disparity and the impact of the capital disparity on the profitability of cooperatives in the agricultural sector from the regional perspective during the monitored period of 2009-2013. However, more detailed analysis in each region could be more explanative and complex.

\section{Acknowledgement}

The paper was elaborated within the research IGA. The title of the research is Capital and wage disparity in the agricultural sector (registration number: 20141031).

\section{Corresponding author:}

Ing. Jana Steklá

Department of Economics, Faculty of Economics and Management, Czech University of Life Sciences Prague, Kamýcká 129, 165 21, Prague, Czech Republic

E-mail: stekla@pef.czu.cz

\section{References}

[1] Abor, J. The Effect of Capital Structure on Profitability: An Empirical Analysis of Listed Firms in Ghana. Journal of Risk Finance. 2005, Vol. 6, No. 5, p. 438-445. ISSN 1526-5943.

[2] Baker, M., Wurgler, J. Market Timing and Capital Structure. Journal of Finance. 2002, Vol. 57, No. 1, p. 1-32. ISSN 1540-6261.

[3] DeAngelo, H., DeAngelo, L. Capital Structure, Payout Policy, and Financial Flexibility. Marshall School of Business, FBE Working Paper. 2007, Vol. 02-06.

[4] Donaldson, G. Corporate Debt Ccapacity: A Study of Corporate Debt Policy and the Determination of Corporate Debt Capacity. Boston: Harvard University, Beard Books. 1961. ISBN 978-158-7980-343.

[5] Fama, E. F., French, K. R. Financing Decisions: Who Issues Stock? Journal of Financial Economics. 2005, Vol. 76, No. 3, p. 549-582. ISSN 0304-405X.

[6] Faulkender, M., Wang, R. Corporate Financial Policy and the Value of Cash. Journal of Finance. 2006, Vol. 61, No. 4, p. 1957-1990. ISSN 1540-6261.

[7] Gill, A., Biger, N., Mathur, N. The effect of capital structure on profitability: Evidence from the United States. International Journal of Management. 2011, Vol. 28, No. 4, p. 3-15. ISSN 1468-2370. 
[8] Graham, J. R., Leary, M. T. A review of empirical capital structure research and directions for the future. Annual Review of Financial Economics. 2011, Vol. 3, No. 1, p. 309-345. ISSN 1058-3300.

[9] Gurčík, L'. G-index - the financial situation prognosis method of agricultural enterprises. Agricultural Economics. 2002, Vol. 48, No. 8, p. 373-378. ISSN 1574-0862.

[10] Guthmann, H. G., Dougall, H. E. Corporate Financial Policy, $3^{\text {th }}$ ed. New York: Prentice-Hall, 1955.

[11] Hirschey, M. Managerial Economics. 12 $2^{\text {th }}$ ed. New York: Cengage Learning, 2008. ISBN 978-0-324-58886-6.

[12] Choi, H. The Kraus-Litzenberger Zero-Sum Trade-Off Theory. Social Science Research Network. 2015. ISSN 15565068.

[13] Chrastinová, Z. Economic and Financial Position of Agricultural Enterprises in the Period before the Accession to the European Union. Agricultural Economics. 2004, Vol. 50, No. 11, pp. 486-494. ISSN 1574-0862.

[14] Jensen, M. C., Meckling, W. H. Theory of the firm: managerial behavior, agency costs and ownership structure. Journal of Financial Economics, 1976, Vol. 3, No. 4, pp. 305-360. ISSN 0304-405X.

[15] King, B. P., Rosopa, P. J., Minium E. W. Statistical Reasoning in the Behavioral Sciences. $6^{\text {th }}$ ed. New York: John Wiley and Sons. 2011. ISBN 978-1-118137-48-2.

[16] Kraus, A., Litzenberger, R. H. A State Preference Model of Optimal Financial Leverage. Journal of Finance. 1973, Vol. 28, No. 4, pp. 911-922. ISSN 1540-6261.

[17] Lang, T. A., Secic, M. How to Report Statistics in Medicine: Annotated Guidelines for Authors, Editors, and Reviewers. $2^{\text {nd }}$ ed. New York: ACP Press,. 2006. ISBN 1-930513-69-0.

[18] Leavy, A. M. Indexing Distributions of Data: Preservice Teachers' Notions of Representativeness. School Science and Mathematics. 2004, Vol. 104, No. 3, p. 119-134. ISSN 1949-8594.

[19] Lemmon, M. L., Roberts, M. R., Zender J. F. Back to the Beginning: Persistence and the CrossSection of Corporate Capital Structure. Journal of Finance. 2008, Vol. 63, No. 4, p. 1575-1608. ISSN 1540-6261.

[20] Mohammadzadeh, M. et al. The Effect of Capital Structure on the Profitability of Pharmaceutical Companies The Case of Iran. Iranian Journal of Pharmaceutical Research. 2013, Vol. 12, No. 3, p. 573-577. ISSN 1726-6890.

[21] Minton, B. A., Wruck, K. H. Financial Conservatism: Evidence on Capital Structure from Low Leverage Firms. Ohio State University, 2001.

[22] Morellec, E. Can Managerial Discretion Explain Observed Leverage Ratios? Review of Financial Studies. 2004, Vol. 17, No. 1, p. 257-294. ISSN 1465-7368.

[23] Myers, S. C., Majluf, N. S. Corporate Financing and Investment Decisions when Firms Have Information that Investors do not Have. Journal of Financial Economics. 1984, Vol. 13, No. 2, p. 187-221. ISSN 0304-405X.

[24] Peterson, P. P., Fabozzi, F. J. Analysis of Financial Statements. 1 ${ }^{\text {st }}$ ed. New York: Wiley, 1999. ISBN 978-1-883249-59-5.

[25] Regionální vyhodnocení výsledků FSS, 2013 [Online]. Available: https://www. czso.cz/documents/10180/26566189/27016815k06.pdf/198a30ba-f3 79-4723-89e7f4413d5ac744?version=1.1 [Accessed: 24 August 2015].

[26] Rosochatecká, E. Economic Efficiency of Agricultural Enterprises and Its Evaluation. Agricultural Economics. 2002, Vol. 48, No. 3, p. 97-101. ISSN 1574-0862.

[27] Shivdasani, A., Stefanescu, I. How do Pensions affect corporate capital structure decisions? Review of Financial Studies. 2010, Vol. 23, No. 3, p. 1287-1323. ISSN 1465-7368. 
[28] Statistické ročenky, Český statistický úřad, 2014 [Online]. Available: https://www.czso.cz/csu/czso/ katalog-produktu [Accessed: 24 August 2015].

[29] Taani, K. Capital Structure Effects on Banking Performance: A Case Study of Jordan. International Journal of Economics, Finance and Management Sciences. 2013, Vol. 1, No. 5, p. 227-233. ISSN 2326-956.

[30] Využití obhospodařované zemědělské půdy, 2013 [Online]. Available: https://www. czso.cz/documents/10180/25404471/27016614086.pdf/84d6c849-884a-4a04-8f84b14f28f4e3fd?version=1.0 [Accessed: 24 August 2015].

[31] Welch, I. Two Common Problems in Capital Structure Research: The Financial-Debt-To-Asset Ratio and Issuing Activity versus Leverage Changes. International Review of Finance. 2011, Vol. 11, No. 1, p. 1-17. ISSN 1468-2443. 